\title{
Action Reflected and Project Based Combined Methodology for the Appropriate Comprehension of Mechanisms in Industrial Design Education
}

\author{
H. Güçlü Yavuzcan, Damla Şahin \\ Deparment of Industrial Product Design, Faculty of Architecture, Gazi University, Ankara, Turkey
}

\begin{abstract}
Article Info
Article history:

Received Jul 24, 2017

Revised Jan 20, 2018

Accepted Jul 26, 2018

Keywords:
Design education
Mechanisms
Design studio
Combined teaching method
Action learning
Project based learning

Keywords:

Design education

Mechanisms

Combined teaching method

ABSTRACT

In industrial design education, mechanics-based courses are mainly based on traditional lecture and they are highly abstract for ID students to comprehend the mechanisms The existing studies highlight the requirement of a new approach for mechanics-based courses in ID departments The study presents, a combined teaching model of mechanism mainly based on applied teaching style and action learning to improve ID students' learning experience and competencies through promoting the transference of theoretical knowledge into practical experience and learning The combined teaching model consisting of 3 phases was integrated to a design studio project that is mechanical game design Project observations and post-questionnaire were employed to analyze objectively the appropriateness of the teaching model The results indicated that, the combined teaching model improved ID students' learning outcomes and competencies in terms of transferring the gained theoretical and practical knowledge to the action learning.
\end{abstract}

Project based learning
Copyright (c) 2018 Institute of Advanced Engineering and Science. All rights reserved.

Corresponding Author:

H. Güçlü Yavuzcan,

Deparment of Industrial Product Design, Faculty of Architecture,

Gazi University, Ankara, Turkey

Email: hgyavuzcan@gmail.com

\section{INTRODUCTION}

Industrial design is not making things beautiful; it is far more than how a product looks like. As a transdisciplinary profession, it covers many areas, including engineering, science, marketing, aesthetics, and anthropology as well as social, cultural and ecological issues [1-5]. It is supposed that the students having good knowledge and skills about these areas are well equipped for employment. Nevertheless, industry's expectations from industrial design graduates chance with the rapid industrial developments [6]. Therefore, ID schools should continuously update their curriculums and modify their teaching methods according to industrial needs.

The [1] categorizes three main competencies that design students should be trained in. These are; 1 ) general qualifications-problem solving, communication skills, etc. ,2) specific industrial design abilities and understanding-design thinking, design process, visualization skills, manufacturing, materials, design management etc. and 3) knowledge aggregation.

Many ID departments in Turkey orientate their educational systems and curricula in order to comply with the above mentioned competencies of their students and they provide multiple courses covering engineering, ergonomics, management, arts, and computer-related areas. [6] interviewed with participants having more than 10 years' experience implementing industrial design and teaching and reported that industrial designers must develop professional competencies in eight dimensions, which are aesthetic literacy, design expression, creativity, planning and integration capability, engineering capability, computer application skills, ergonomics knowledge, and foreign language skills. For the sub-categories (knowledge of manufacturing processes, capability of material usage, knowledge of mechanical designing and principles) of 
the engineering capability dimension, knowledge of mechanical designing and principles is reported as the most important item. ID students need a considerable understanding of mechanisms in addition to manufacturing processes and material to create innovative ideas. Since the mechanism forms affect both the function and the appearance of the product, it is vital for students to have sufficient knowledge of mechanism to start a design for relatively complicated product. To be able to actualize proposed function for a new design idea, students have to be able to predict which mechanisms could be effectively used. Throughout professional life, as an industrial designer they will be also responsible for mechanical details of their product designs. However, mechanical design courses are generally tend to be taught through traditional methods, mainly depends on verbal lectures. Video-based three-dimensional animations are also not sufficient for design students due to their lack of knowledge of mechanical mechanism [7], visual and video-based lectures are highly abstract to comprehend the practical aspects of the mechanisms particularly used for the transfer and activate the motion of which the design students care more for their further professional life.

Traditional lecture-based teaching and learning method, supported with appropriate laboratory activities is generally common and accepted among engineer students. However, design students are hesitative about convergent learning styles and strongly prefer applied learning methods that provide active experimentation although they are aware of the benefits of engineering-based education [8]. Majority of design students are not satisfied with the teaching methods applying to the Mechanical Design courses [7, 8]. In addition, Bingham et al [8] have reported that according to the outcomes of Final Year Design Practice Projects at Loughborough University, mechanical design and functionality were used inappropriate. Liu et al [7] examined the 1500 student works submitted to Chinese Hardware Products Industrial Design Competition and reported that less than $10 \%$ of the students' utilized advanced mechanical concepts, the rest of the works were based on styling, which indicates the limited mechanical design ability of industrial design students. There is limited research on the engineering-based learning of ID students. Chou and Hsu [9], indicated that different from engineers, industrial designers rely more on creative problem solving than procedural knowledge, and therefore they need a fundamental training of scientific thinking, in which they may learn how to expand their knowledge domain efficiently. They concluded that, in the long run, well-designed and certificated PBL (problem-based learning) problems for design sciences and technologies can be organized to form a data base, forming a teaching resource for all courses in their department of industrial design.

Thus, the existing studies highlighted that design students need a new approach for engineeringbased courses and complementary courses and studios that would need holistic perspectives. The aim of this study was to present a combined teaching and learning model for mechanism included products so called blended learning mainly based on applied learning style together with the functional theory and active experimentation to improve ID students' practical learning experience. To achieve this, teaching model, consisting of 3 phases, was integrated to the design studio project (4th Semester) to promote the transfer of the theoretical knowledge obtained in the prior lecture of "Mechanisms" into practical and concrete learning by doing experience. The integration was important to analyze the contribution of the model to the design process and to reveal the students' knowledge of mechanism through final product designs.

\section{TEACHING OF MECHANISM IN INDUSTRIAL DESIGN EDUCATION}

Engineering-based courses in the main ID departments in Turkey are generally taught either by instructors from Mechanical Engineering Departments or by industrial design instructors with a professional background in engineering. Engineering-based must courses in main ID departments of Turkish Universities are indicated in Table 1. As seen in Table 1, mechanics-based courses only exist in some universities' curricula. In Gazi University, Mechanism and Details course was added to the curriculum in 2014-2015 academic year.

Table 1. Engineering-based courses in ID departments

\begin{tabular}{|c|c|c|c|c|c|c|c|c|}
\hline $\begin{array}{l}\text { Engineering- } \\
\text { based courses }\end{array}$ & Gazi Uni. & $\begin{array}{l}\text { Middle East } \\
\text { Technical Uni. }\end{array}$ & $\begin{array}{l}\text { Istanbul } \\
\text { Technical Uni. }\end{array}$ & & $\begin{array}{l}\text { Izmir } \\
\text { University of } \\
\text { Economics }\end{array}$ & $\begin{array}{l}\text { Anadolu } \\
\text { Uni. }\end{array}$ & $\begin{array}{l}\text { Bahçeşehir } \\
\text { Uni. }\end{array}$ & $\begin{array}{l}\text { Marmara } \\
\text { Uni. }\end{array}$ \\
\hline $\begin{array}{l}\text { Mechanics- } \\
\text { based }\end{array}$ & $\begin{array}{l}\text { Mechanism } \\
\text { and Details }\end{array}$ & & $\begin{array}{l}\text { Introduction } \\
\text { Mechanical } \\
\text { Design }\end{array}$ & to & & & $\begin{array}{l}\text { The Way } \\
\text { Things Work }\end{array}$ & $\begin{array}{l}\text { Design } \\
\text { Constructio } \\
\mathrm{n}\end{array}$ \\
\hline $\begin{array}{l}\text { Manufacturin } \\
\text { g-based }\end{array}$ & $\begin{array}{l}\text { Manufactur } \\
\text { ing } \\
\text { Methods }\end{array}$ & $\begin{array}{l}\text { Principles of } \\
\text { Production } \\
\text { Engineering }\end{array}$ & $\begin{array}{l}\text { Manufacturing } \\
\text { Methods }\end{array}$ & & $\begin{array}{l}\text { Production } \\
\text { Technologies }\end{array}$ & $\begin{array}{l}\text { Manufacturi } \\
\text { ng Methods }\end{array}$ & & $\begin{array}{l}\text { Production } \\
\text { Techniques }\end{array}$ \\
\hline $\begin{array}{l}\text { Material- } \\
\text { based }\end{array}$ & Materials & $\begin{array}{l}\text { Manufacturing } \\
\text { Materials }\end{array}$ & $\begin{array}{l}\text { Statics } \\
\text { Strength } \\
\text { Materials }\end{array}$ & $\begin{array}{l}\& \\
\text { of }\end{array}$ & $\begin{array}{l}\text { Materials for } \\
\text { Industrial } \\
\text { Design }\end{array}$ & $\begin{array}{l}\text { Material } \\
\text { Science }\end{array}$ & $\begin{array}{l}\text { Manufacturin } \\
\text { g Materials }\end{array}$ & $\begin{array}{l}\text { Material } \\
\text { Technology }\end{array}$ \\
\hline
\end{tabular}


Through the learning outcomes indicated in Table 2, it is seen that the courses in Gazi University and Istanbul Technical University covers mechanism and mechanical design issues in detail, whereas other two courses (The Way Things Work and Design Construction) includes these issues partially.

Table 2. Summary of the courses

\begin{tabular}{|c|c|c|c|c|}
\hline & Gazi Uni. & Istanbul Technical Uni. & Bahçeşehir Uni. & Marmara Uni. \\
\hline Course Names & Mechanism and Details & $\begin{array}{l}\text { Introduction to Mechanical } \\
\text { Design }\end{array}$ & The Way Things Work & Design Construction \\
\hline $\begin{array}{l}\text { Learning } \\
\text { outcomes }\end{array}$ & $\begin{array}{l}\text { 1. Understand the basic } \\
\text { mechanisms components } \\
2 . \text { Understand and } \\
\text { interpret the mechanism } \\
\text { and connection types } \\
\text { 3. Have full knowledge } \\
\text { of exploded view and } \\
\text { detail display through } \\
\text { mechanisms } \\
\text { 4. Understand the place } \\
\text { and contribution the } \\
\text { solution of electronic } \\
\text { circuits in mechanism } \\
5 . \text { Develop mechanism } \\
\text { based problem solving }\end{array}$ & $\begin{array}{l}\text { 1. Understand the } \\
\text { fundamentals of mechanical } \\
\text { systems } \\
\text { 2. Understand the physical } \\
\text { principles of mechanical } \\
\text { systems } \\
\text { 3. Understand the basic } \\
\text { elements used in mechanical } \\
\text { systems } \\
\text { 4. Develop the basic skills for } \\
\text { analyzing existing } \\
\text { mechanisms } \\
\text { 5. Develop the skills to find } \\
\text { mechanical solutions during } \\
\text { designing }\end{array}$ & $\begin{array}{l}\text { 1. To identify } \\
\text { assembling and } \\
\text { disassembling } \\
\text { procedures of objects in } \\
\text { order } \\
\text { 2. To explain the } \\
\text { circular movement, } \\
\text { linear movement and ex- } \\
\text { centric movement } \\
\text { 3. To differentiate the } \\
\text { elements of simple } \\
\text { mechanics } \\
\text { 4. To apply the } \\
\text { principles of simple } \\
\text { mechanics to the new } \\
\text { design of objects } \\
\text { 5. To compare various } \\
\text { power sources } \\
6 \text {. To support the } \\
\text { mechanics and working } \\
\text { principles of objects } \\
\text { with the renewable } \\
\text { energy sources }\end{array}$ & $\begin{array}{l}\text { 1. To evaluate design } \\
\text { from a different } \\
\text { perspective } \\
2 \text {. To examine about } \\
\text { design development } \\
\text { process and } \\
\text { development of its } \\
\text { applications } \\
\text { 3. To identify both } \\
\text { design and engineering } \\
\text { contexts about statics, } \\
\text { dynamics and mechanics } \\
4 \text {. To analyze the basic } \\
\text { principles of physics in } \\
\text { the context of industrial } \\
\text { design } \\
5 \text {. To explain the } \\
\text { relationship between } \\
\text { design and construction }\end{array}$ \\
\hline Assessment & Midterm exam & Homework Assignments & Homework Assignments & Homework Assignments \\
\hline Criteria & Final exam & $\begin{array}{l}\text { Quizzes } \\
\text { Midterm project } \\
\text { Final project }\end{array}$ & $\begin{array}{l}\text { Quizzes } \\
\text { Midterm exam } \\
\text { Final exam }\end{array}$ & $\begin{array}{l}\text { Midterm exam } \\
\text { Final exam }\end{array}$ \\
\hline
\end{tabular}

The courses summarized above are generally lecture-based with a high degree of abstraction. As seen in Table 2, the outcomes of these courses generally evaluated through quizzes, midterm and final examinations and homework assignments. Therefore, students do not have the opportunity to transfer theoretical knowledge into practical achievements throughout the course period.

In contemporary design education, the courses are divided in four categories: 1) fundamental courses 2) technology-based courses 3) artistic courses 4) design studio courses [10-12]. Second category, technology-based courses, consists of the courses that are theoretical based but directly related to practice named as construction, structure, material etc. [12]. Accordingly, engineering-based courses belongs to the second category. This implies that students' acquired knowledge in mechanics-based courses should be not only theoretical but also practice-based. It is widely accepted that theoretical teaching style alone is insufficient to equip design students with the skills required during professional life [13]. Design educators look for teaching models that form combination of theories, techniques and skills to reflect the students' individual approaches $[10,14]$. Therefore, it is essential to combine theoretical knowledge with real-world practical experience for design students.

In design education, design studio courses are the most crucial part and they are the synthesis of all other courses [10]. The aim of the courses except design studio courses is to provide students with theoretical and practical knowledge that they can utilize in design studio projects. However, it is seen that there is no concrete bridge between the design studio courses and mechanics-based courses. Although students gain sufficient theoretical and practical knowledge of mechanisms, they have difficulties in applying this knowledge to a real design project. Thus, there is a need for a new teaching model of mechanism for ID students combining theoretical and practical knowledge with an applied learning style. 


\section{DESIGN OF NEW TEACHING MODEL OF MECHANISM}

\subsection{Methodology}

The implementation was conducted at Gazi University, the department of Industrial Product Design within second-year 'Product Design II' course. The aim of this application was to improve ID students' learning experience on mechanical mechanism by utilizing applied learning style and to provide them to transfer their knowledge of mechanism into design project.

In consequence of the above discussions, a new teaching model of mechanism that combining different styles but mainly based on applied learning style covering active experimentation (learning by doing) and concrete experience (learning by experiencing) was designed. This teaching model was integrated to design project and conducted thoroughly within product design-studio course.

New teaching model consists of three main phases: Improving theoretical knowledge of mechanism and possible applications, in depth practical knowledge of specific mechanism and application of mechanism into design a process (Figure 1).

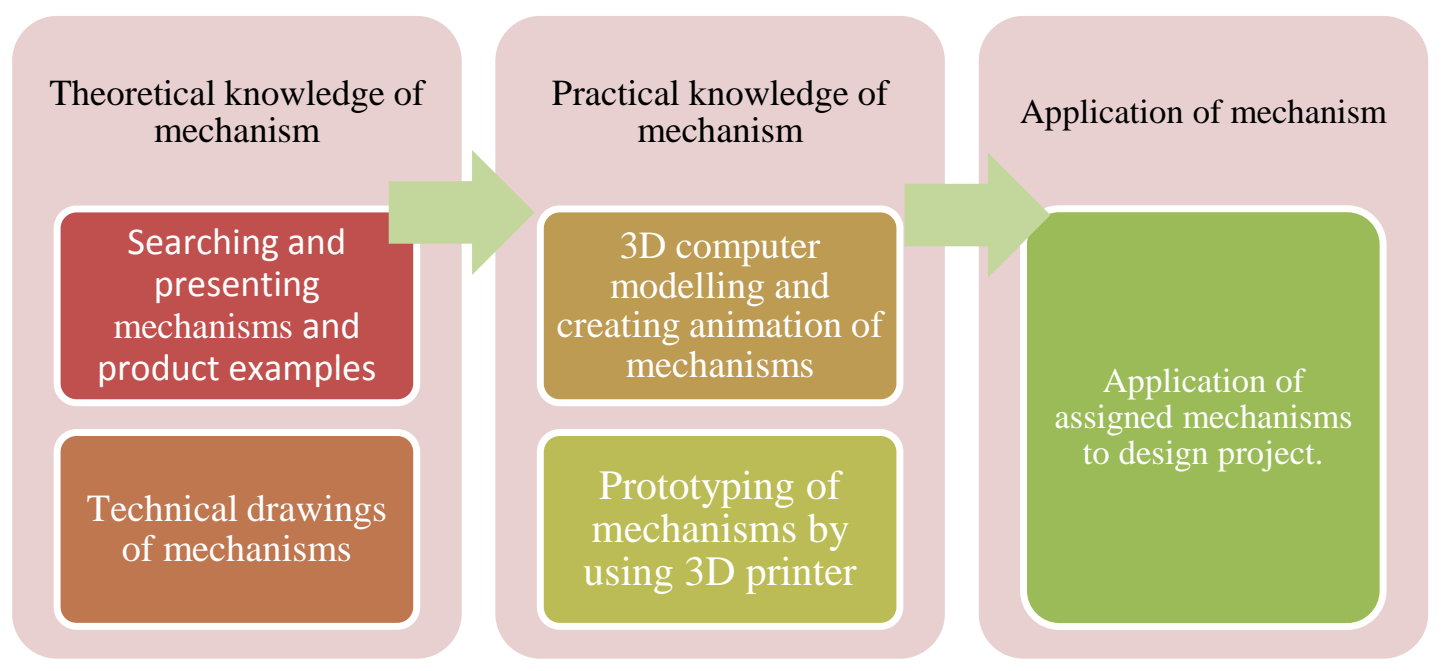

Figure 1. Phases of new teaching model of mechanism

Improving theoretical knowledge of mechanism and possible applications: This phase consists of searching and presenting working system of mechanisms and mechanism-based product examples including the technical drawings and related 3D animations. The teaching method specified a series of reference materials for students' self-study to improve and revise their knowledge obtained in previous courses. Concrete outcome oriented presentations were requested and apart from the recommemded self-study materials, students are allowed to reach all related the information about assigned mechanisms for reinforcing their knowledge through drawing different perspectives. Some amount of the mathematical content was removed except for two sections related to planar linkage degrees of freedom and transmission system speed ratios that are esential for the holistic approach of the final product. Mechanical applications in industrial design mainly are concentrated on the motion mechanisms. Therefore, most of the assigned mechanisms classified basing on their level of complexity were focused on planar mechanisms and transmission systems. The functions of the planar mechanisms were requested to be solved in terms of their operatiove systems such as copying, changing direction, scaling and other basic operations. Students abstract general principles of the assigned mechanisms around their environment in order to build mechanical knowledge through their intiative in studying the everyday objects. Afterwards, the students are guided toward drawing conclusions on theoretical knowledge through practical life conditions. During the studio criticisms, combined applications in problem-solving are carried out to give students experience in analysing situations while, at the same time, seeking solutions to problems through theoretical principles.

Within this process, their skills in appliying knowledge were strenghtened and their analysis were encouraged with additional 3D animations and video presentation of typical mechanical products as well as necassary detailed technical drawings including perspectives, different views and sectional views.

In depth practical knowledge of specific mechanisms: This phase consists of 3D computer modeling and animation of the assigned mechanisms and creating the prototype of the mechanisms by using 3D printer.

Action Reflected and Project Based Combined Methodology for the Appropriate ... (H. Güçlü Yavuzcan) 
The ultimate goal for industrial design students, who study courses on mechanical design, is to increase their advantage in product design and to eliminate the biased common impression that industrial design is just styling [7]. The authors' department was equipped with 3D printers, allowing students to turn their modelled mechanisms into concrete models, which greatly enhances also their knowledge of modelling obtanied in computer aided design courses. In this stage, students actively learn mechanisms by doing and experiencing. In case of false scaling, the students re-modelled the assigned mechanism until it matches with appropriate output from 3D printer. They test and improve the design of the mechanism by modifying the scales, features and mechanical functions of the virtual models by adjusting the parameters. Thus, the modelling and testing capabilities of the students were increased in terms of developing a full understanding of their own mechanisms, both theoretically and perceptually.

Application of mechanism into a design process (action learning): In this phase, students apply the mechanisms in a specific real design project. Students are requested to develop a product including their assigned mechanism after the completion of phase 1 and appropriate modelling in phase 2 . Thus, better comprehension of creating functional prototype through the active application of the assigened mechanism was the main learning outcome of this final phase. In some drafts of the integrated design cases, the training and implementation was even carried out on combined applications of more than one mechanisms.

According to above mentioned phases of proposed teaching model, design brief and assignments were formed as indicated in Section 3.

\subsection{The Project Brief: Mechanical Game Design}

To apply the new teaching model of mechanism to design-studio project, many product ideas while preparing design brief were discussed in terms of their suitability to assigned mechanisms, complexity and approximate duration. Since the main purpose of the project was to provide students to gain practical knowledge of mechanism, mechanism should have not played recessive role in the product. Therefore, it was decided to constitute a project brief for mechanical game design. It was thought that mechanical game design project allows more alternatives for the students in terms of both creativity of the final product and appropriate application of mechanisms.

The anticipated steps while preparing design brief and assignments are as follows:

Specifying mechanisms: Mechanisms assigned to the students were judged according to their suitability to mechanical game design project. As product designers utilize generally movement mechanisms in their products [7], this type of mechanisms were chosen to assign to the students. These mechanisms were distinguished into three categories in terms of their relative complexity (Table 3 ).

Forming teams: A total of 41 industrial design sophomore attending a 'Product Design II' course participated in the project. The demographic makeup included 34 females and 7 males. Students were formed in teams consisting of three members.

Assigning mechanisms: All teams have chosen one mechanism from each of three mechanism categories. All the members of each team were responsible for the detailed analysis of three mechanisms that they have chosen for the first phase of the training process.

Table 3. Three categories of movement mechanisms

\begin{tabular}{llll}
\hline \multicolumn{1}{c}{ Less complex } & \multicolumn{1}{c}{ Complex } & \multicolumn{1}{c}{ More Complex } \\
\hline 1 & Worm Wheel & Crankshaft-Rod & Cardan Gear \\
2 & Sprocket Wheel & Bellcrank & Universal Joint \\
3 & Belt-pulley & Camshaft & Geneva Drive \\
4 & Bar-Pendulum Linkage & Drop/Snail Camshaft & Internal Geneva Drive \\
5 & Double Pendulum & Scotchyoke & Planet Gear \\
6 & Hoekens Linkage & Ratchet Wheel & Looney Gear \\
7 & Ball Joint & Scissors Mechanism & Chuck \\
8 & Gear Train & Scissors Jackscrew & Iris Diaphragm \\
9 & Elliptical gear & Bevel Gear & Variable Speed Gears \\
10 & Torsion Spring & Helical Gear & Anchor Escapement \\
11 & Archimedes' Screw & Tusi-Couple & Ferguson's Paradox \\
12 & & Centrifugal Governor & Withworth Mechanism \\
13 & & & Barrel/Cylindrical Cam \\
\hline
\end{tabular}

\section{Phase 1: Improving theoretical knowledge of mechanism and possible applications:}

Assignment 1: Teams were asked to search mechanisms assigned to $(3$ mechanisms ranging from less complex to more complex) them. Searching included materials describing the principles of mechanisms via both visual (technical drawings, renders of 3D computer models and pictures) and video-based as the 
details are mentioned in Section 3.1. In addition, to gain concrete knowledge about mechanisms, the products or systems around their environment that these mechanisms are utilized were also searched. Teams were also asked to make technical drawing of all three mechanisms. They submitted and presented all assignments to the instructors. At the end of this phase, 3 mechanisms assigned to the teams were reduced to two for further in depth analysis and 3D modeling basing on the their exhibited competencies and their interest on the mechanisms through the samples of real life conditions providing that, interest is the main motivator in stimulating students' passion for learning and research.

\section{Phase 2: in depth practical knowledge of specific mechanisms:}

Assignment 2: Basing on the selection of two mechanisms per each team, the students started in depth analysis on two mechanism system each team created 3D models of these mechanisms by using Autodesk Fusion 360. Teams also set up a motion study in Fusion 360 to analyze their operative systems and movements (rotations, translation, transmission, changing directions etc.) of the parts of mechanism an tested whether it worked appropriately or not. The methodology of the process has been fulfilled as mentioned in Section 3.1.

After the presentations of the 3D models and motion studies of the two mechanisms per each team, the instructors, basing on the interest, motivation and previous studies of the students for providing a gap with their environment, have chosen and assigned one mechanisms per each (Table 4) for further 3D printing process.

Assignment 3: 3D models created in Fusion 360 were examined by instructors to make them ready for $3 \mathrm{D}$ printing. Thickness of the parts, tolerances between the parts and overall scales of the models were optimized according to existing 3D printer features. All prototypes of mechanisms created by using Zortrax M200 within the GAZİ D-LAB (Digital Design Laboratory of Gazi University).

Table 4. Mechanisms assigned to teams

\begin{tabular}{ll}
\hline Teams & Mechanisms \\
\hline Team 1 & Centrifugal Governor \\
Team 2 & Drop/Snail Camshaft \\
Team 3 & Scotchyoke \\
Team 4 & Worm Wheel \\
Team 5 & Crankshaft-Rod \\
Team 6 & Universal joint \\
Team 7 & Archimedes' Screw \\
Team 8 & Planet Gear \\
Team 9 & Ferguson's Paradox \\
Team 10 & Iris Diaphragm \\
Team 11 & Camshaft \\
Team 12 & Geneva Drive \\
Team 13 & Cylindrical Cam \\
Team 14 & Withworth Mechanism \\
\hline
\end{tabular}

\section{Phase 3: Application of mechanism into a design project (action learning):}

Mechanical Game Design: After assigning the mechanisms that each team was responsible for, the process for designing a game based on the assigned mechanism have been initialized. This process is also called as "action learning" and the project subject have been chosen in order to minimize the possible negative pressure and impacts on the students' creative thinking.

The main specifications for mechanical game design were as follows:

a. Teams have to apply the mechanism assigned to them at least once in the active systems of their designs. In case of more complex system designs, they can add additional mechanisms where required.

b. The product should be manually operated or powered.

c. There is no limitation on material usage and scale of the product.

d. The product can be designed for different age groups.

Working in teams of three students, each team had a total of 5 weeks (Total 40 hours of active studio hours and approximately 70 hours of work outside studio hours including research, case studies and practices) to finalize the product design. Within first 4 weeks, teams developed design ideas and formed them as design proposals through studio critiques. They presented their two design proposals including research report, technical and perspective drawings and 1/1 physical mock-ups in preliminary jury. Instructors chose one of two proposals that teams will continue to improve until final jury. Each team finalized and presented their mechanical game designs at the end of $5^{\text {th }}$ week. 


\subsection{Project Management}

To manage the project lifecycle the students' submissions and timing were important. Sequence of the submissions were arranged parallel with the project brief. The duration of each submission were developed by regarding the students' previous project performances. All submissions and timing of the stages are demonstrated in Table 5.

Table 5. Submissions and timing

\begin{tabular}{|c|c|c|}
\hline Project Phases & Week & Submissions \\
\hline \multirow{5}{*}{ Theoretical knowledge of mechanism } & 1 & Team member selection \\
\hline & & Assignment 1 \\
\hline & & -Research report on 3 mechanisms \\
\hline & & -Presentation of detailed technical drawings of mechanisms \\
\hline & & -Selection of 2 mechanisms per each team for further phase \\
\hline \multirow[t]{6}{*}{ Practical knowledge of mechanism } & 2 & Assignment 2 \\
\hline & & -3D modeling of two mechanisms in Fusion 360 \\
\hline & & -Motion study of two mechanisms in Fusion 360 \\
\hline & & - Selection of one mechanisms per each team for 3D prototyping \\
\hline & 3 & Assignment 3 \\
\hline & & - 3D printed prototypes of the selected mechanisms \\
\hline \multirow{5}{*}{$\begin{array}{l}\text { Application of mechanism } \\
\text { Mechanical Game Design }\end{array}$} & 4 & Preliminary Jury \\
\hline & & -Presentation of research, technical and perspective drawings \\
\hline & & -1/1 physical mock-ups \\
\hline & $J$ & -Presentation of research, technical and perspective drawings \\
\hline & & -1/1 physical model \\
\hline
\end{tabular}

\section{EVALUATION OF THE NEW COMBINED MODEL}

To be able to evaluate teaching model effectively, the project was conducted during the second semester of the 2016/2017 academic year since the participating students taking Product Design II course had studied Mechanisms and Detail course in previous semester. Therefore, they were anticipated to appropriately evaluate their learning outcomes and compare their practical improvements and competencies with respect to the gained knowledge and skills in the previous related courses. Since the interest is the main motivator in stimulating students' passion for learning and research, to evaluate the proposed new teaching model, two data capture techniques were employed:

$$
\begin{aligned}
& \text { - } \quad \text { Project observations } \\
& \text { Post-project questionnaire }
\end{aligned}
$$

\subsection{Project Observations}

During twice a week studio critiques ( 8 hours per week), evaluative feedback was provided to teams for their design ideas. Feedback was beneficial for both learning and application of mechanisms in design process. Studio critiques were important to record the attendance and the progress of each team and to analyze the appropriateness of proposed teaching model.

\subsection{Post-Project Questionnaire}

Post-project questionnaire was administered following the final assignment. 37 participants completed it during the final day of the project. To get evaluative feedback about effectiveness of the proposed teaching model, a 4-part questionnaire was developed using Likert scale. In the first part of the questionnaire, the impact of the project phases (research, technical drawings, 3D computer modeling, animating, 3D printing, creating concept ideas, and application of mechanism in product) on learning mechanism were rated, with 1 corresponding to "minimum" and 5 corresponding to "maximum". In the second part, participants were asked to explain which phase of the project was the most challenging. In the third part, participants were asked to rate their level of knowledge on Autodesk Fusion 360 and 3D printing for before and after the project. In the final part, participants were instructed to rate the acceptability of the sentences on a Likert scale of 1 to 5 , with 1 corresponding to "strongly disagree" and 5 corresponding to "strongly agree". Basic statistical values were observed in all parts were as in part 3 paired sample t-test was applied in order to observe the improvements in Autodesk Fusion 360 and 3D printing before and after the use of the teaching methodology. 


\section{RESULTS}

41 industrial design sophomore attending 'Product Design II' course participated in the mechanical game design project, resulting in 14 student teams. All teams finalized the mechanical game design project to different levels of different aspects. The results gained from two data capture techniques: project observations gathered by instructors throughout the process and the post-questionnaire conducted with participating students at the end of the project.

\subsection{Results of the Process Observations}

To analyze the appropriateness of the phases of the project separately, the project discussed for each phase through the process and the submissions.

\section{Phase 1: Improving theoretical knowledge of mechanism and possible applications:}

As mentioned before, In this phase, teams were asked to search mechanisms and make technical drawings of these mechanisms (3 mechanisms ranging from less complex to more complex) assigned to them. The aim was to gather information about mechanisms and how these mechanisms are utilized in products. While some teams' research was limited with the proposed reference materials and internet search, some start to work with physical mechanisms. Physical mechanisms allowed teams to comprehend motion of the mechanisms easier. Majority of research presentations was limited with only google images and texts. Through detailed technical drawings, it was aimed to enable students to learn the parts composing the mechanisms and comprehend the motion and transmission system. It was observed that, teams with insufficient research had trouble while making technical drawings especially in dimensioning and scaling of the parts of the mechanisms. Although these applications were not sufficient for fully understanding motions of the mechanisms, students had improved their general knowledge of mechanisms at the end of this phase. After appropriate guidance, most of the students have been able to abstract general principles of the assigned mechanisms around their environment and tried to provide a gap between the mechanism and practical life conditions. Approximately, half of the student groups even tried to analyse situations that needs combined applications that requires at least two or more mechanisms in a relatively complex system.

\section{Phase 2: In-depth practical knowledge of specific mechanisms:}

As mentioned before, teams were assigned to create 3D models and animation of their mechanisms by using Autodesk Fusion 360 in this phase. Teams struggling while dimensioning the related parts of the mechanisms had also trouble while 3D modeling in Autodesk Fusion 360. Deciding wall thicknesses, tolerances between the parts and calculating gear ratios were some of the challenges teams faced. With instructors' directions, each team revised their Fusion models. The most challenging stage for teams was animating of the mechanisms as they had not sufficient knowledge on making animation in Fusion 360. Despite these difficulties, nearly all teams succeeded in making animation of their mechanisms at the end. Some examples of teams' 3D models created by Autodesk Fusion 360 are demonstrated in Figure 2.
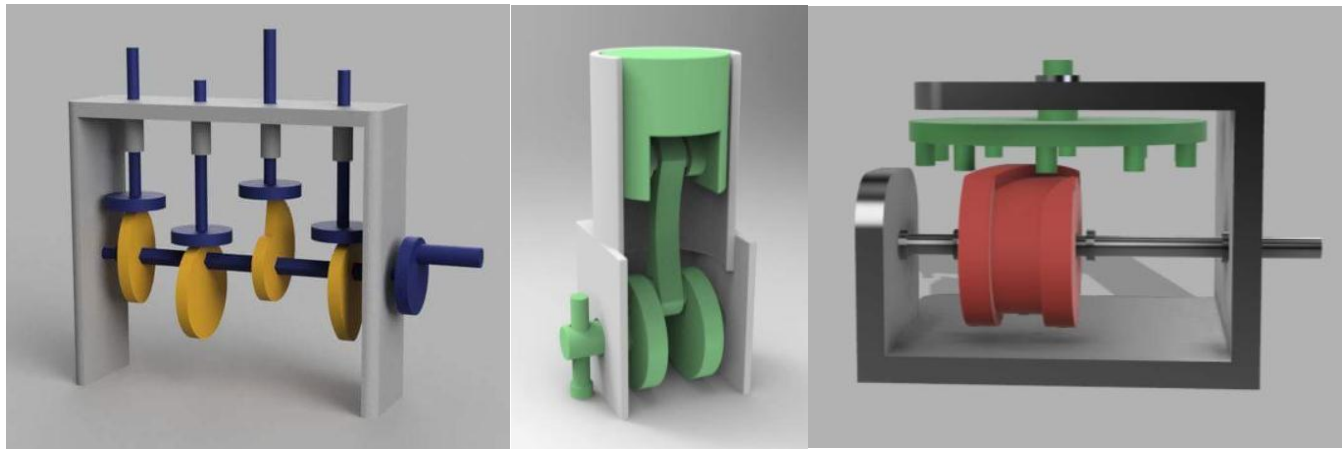

Figure 2. Examples of teams'3D models created by Autodesk Fusion 360

Following 3D modeling, again with the support of instructors, models were optimized for 3D printing. Wall thicknesses and tolerances of the models were revised according to the features of 3D printer. In spite of all these optimizations, some errors occurred while 3D printing. Some parts of the models could not fit together due to insufficient tolerances. In addition, low wall thicknesses of some parts resulted in breaking these parts. However, these problems encountered during 3D printing allowed students to see 
concretely their mistakes made during 3D modeling. All teams' final 3D printed mechanism models are demonstrated in Figure 3.
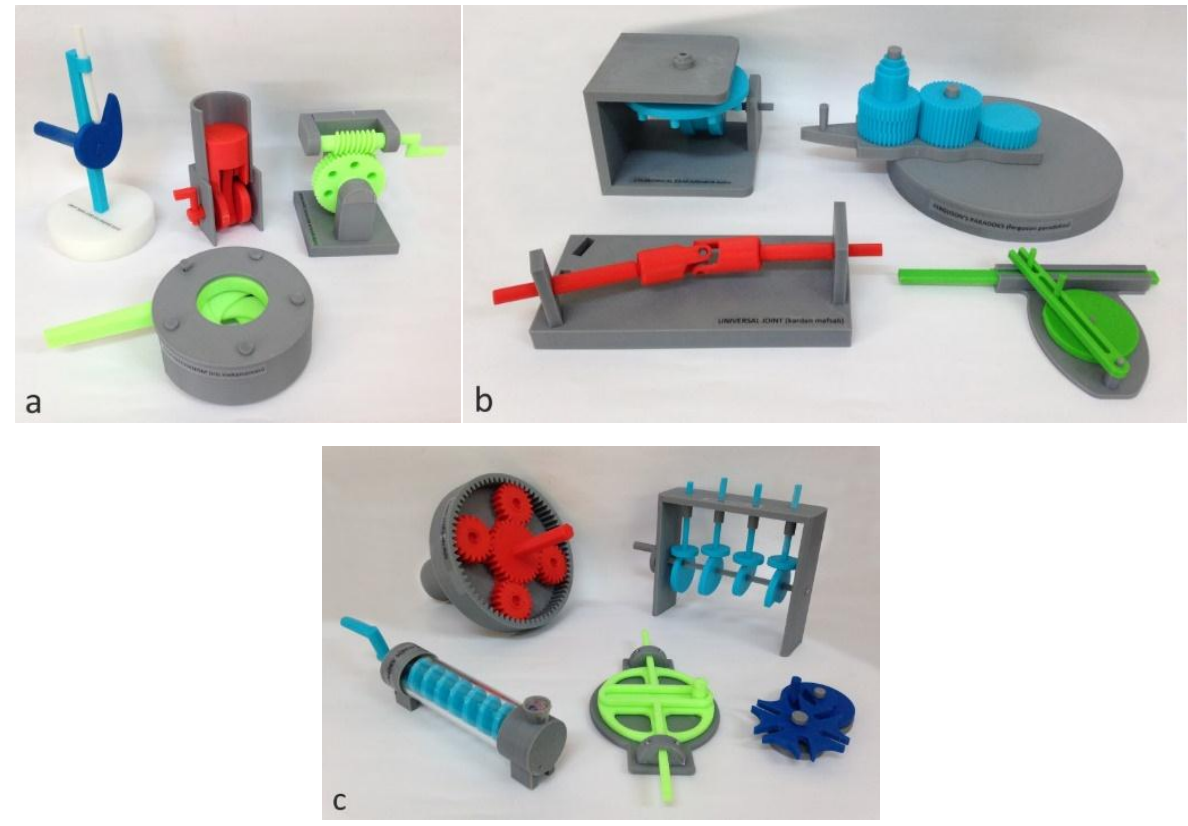

Figure 3. Teams' final 3D printed mechanism models a) Drop Camshaft, Crankshaft-Rod, Worm Wheel, Iris Diaphragm b) Cylindrical Cam, Ferguson's Paradox, Universal Joint, Withworth Mechanism c) Planet Gear, Camshaft, Archimedes' Screw, Scotchyoke, Geneva Drive

Phase 3: Application of mechanism into a design project (action learning):

In this phase, the aim was to apply knowledge acquired while phase 1 and 2 to the design process and action learning. Each team created mechanical game design ideas depending on mechanisms assigned to them. All students engaged in the process using design techniques by making sketches and mock-ups. It was observed that although students were generally motivated to the project, they found the process challenging. Student comments revealed that most of them comprehended the principles of the mechanisms but had difficulties to apply the mechanisms to the product design. They thought that limited with a specific mechanism also limited them in creating product ideas. In fact, this limitation enabled them to focus a specific function and created a starting point for them. During initial phase, the most common mistake was inappropriate application of mechanisms to the design. They struggled creating product ideas relevant to their mechanisms. During studio critiques, some of their design alternatives eliminated and they were directed to develop appropriate concepts. This helped remove their uncertainty and focus on. Physical models developed in this process also allowed students to evaluate their design decisions. Eventually, students understood the importance the transferring theoretical knowledge to practice and apply relevantly to a real product design process. Working in a team helped learning to share a responsibility and develop working discipline. These all were significant outcomes that expected from this new teaching model. Despite the difficulties of the process, all teams succeed in finalizing their product designs with fulfilling all the requirements.

Some of final products of the teams are shown in Figure 4 and summarized as follows:

\section{Team 2- The Earthquake}

It is a board game utilized drop camshaft mechanism. It can be played with 2 or in teams. The aim of the game is to create arrangement on the card drawn by the competitor with the blocks within a certain period of time. The player selects a card from the decks and opens the card as soon as the timer attached to the platform is set. He tries to align the blocks as in the card. When the time is up, the platform suddenly falls and knocks over the blocks. If the game is completed correctly in time, the player gets the point written on the card.

Team 8-Complete the shape

The one-player game is based on a planetary gear mechanism consisting of 1 environment, 1 sun, and 3 pinion gears. With the principle of planetary gear mechanism, the two bearings always rotate together, 
depending on the rotated bearings. The goal of this game to complete the shape by rotating the disks attached to the gears.

\section{Team 9- The Paradox Dart Board}

Differently from dart board game, it has three rotating boards, which makes it more challenging. Ferguson's Paradox mechanism allows rotating boards in different speeds and directions. It can be played with 2 or in teams. The game consists of two parts. In the first part, the players try to shoot in positive areas to get points. In the second part, the players try to shoot in negative areas to reduce the score of the opposing players. The players with the highest score win the game.

Team 10- The Brain Pit

The game contains a perforated board and an iris diaphragm mechanism under it. Each player selects a pion to start the game from the outer of the board. The player who could not answer the question in the cards correctly move his pion one-step further. At the end of each tour, iris diaphragm opens which means the nearest the player to the center, the highest he has risk to fall in the brain pit. The last player not falling in the pit wins the game.

\section{Team 11- The Climbing Game}

The game has a two-sided platform, which consists of stairs. The stairs attached to the camshaft can raise and lower pressing the button. The players try to reach the balls to the top of the platform by raising and lowering the stairs. The balls reaching the top are added to the opposing player's ball pool. The player who finishes the balls first wins the game.

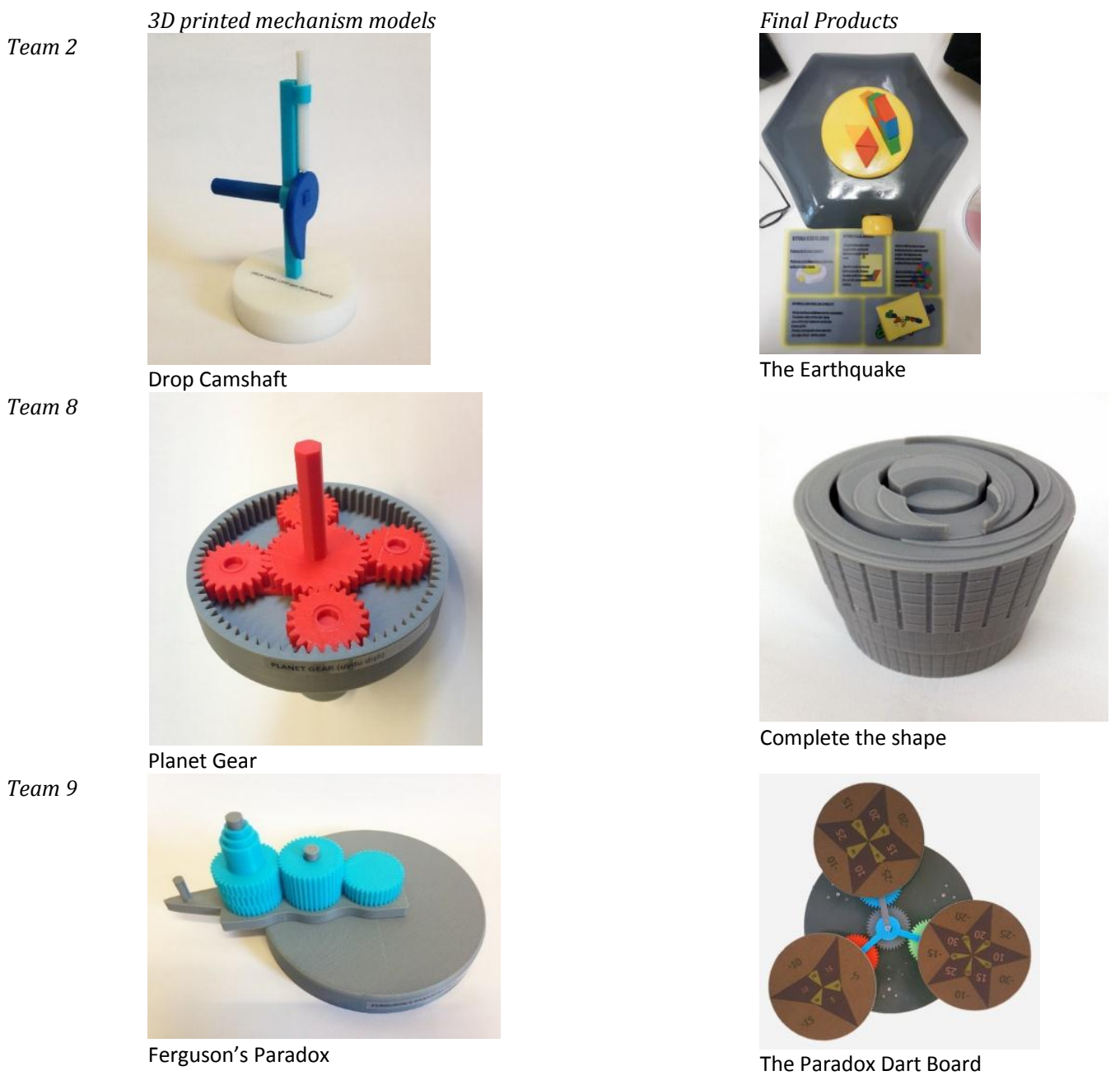




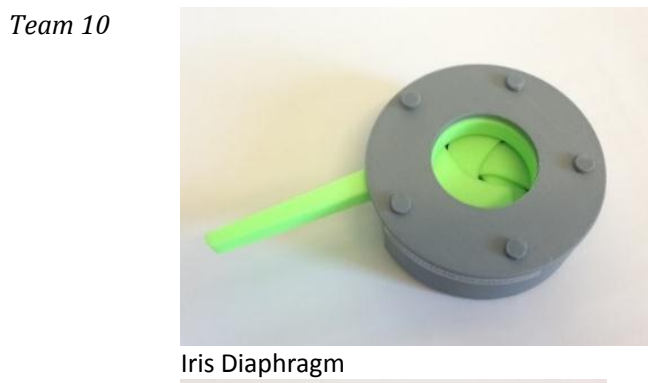

Team 11

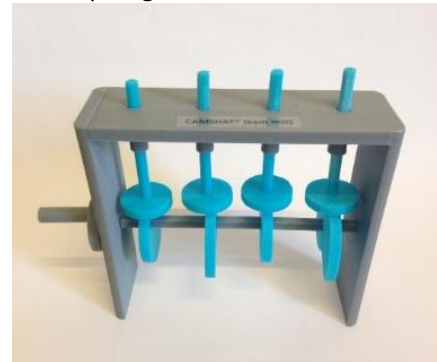

Camshaft

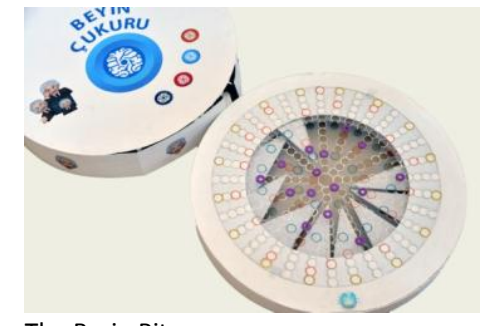

The Brain Pit

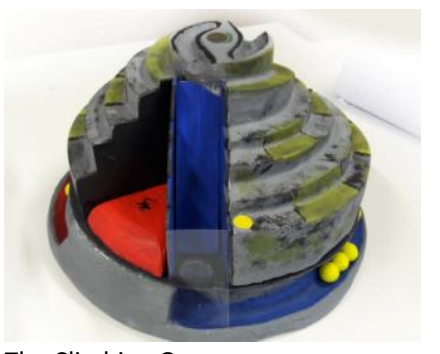

The Climbing Game

Figure 4. Some of final products of the teams together with their mechanism models

\subsection{Post-Project Questionnaire Results}

From 41 students participated in the project, 37 completed the questionnaire. The 4-part questionnaire results are as follows.

Part 1: In this part, students rated the impact of project phases (research, technical drawing, 3D computer modeling, animating, 3D printing, creating concept ideas, and application of mechanism to design project) on the learning outcomes regarding mechanisms.

As seen in Figure 5, "3D computer modeling" and "Application to design project (action learning)" received the most $5=$ maximum responses with $56,8 \%$ and $45,9 \%$ respectively. The impact of " $3 \mathrm{D}$ printing" evaluated as $5=$ =maximum with $43,2 \%$. The mean of the all the responses to "3D computer modeling" was 4,35 (highest in the data set) with a standard deviation of 0,949. "Technical drawing" and "research" received the lowest $5=$ maximum response with $21,6 \%$ and $16,2 \%$ respectively (Table 6 ).

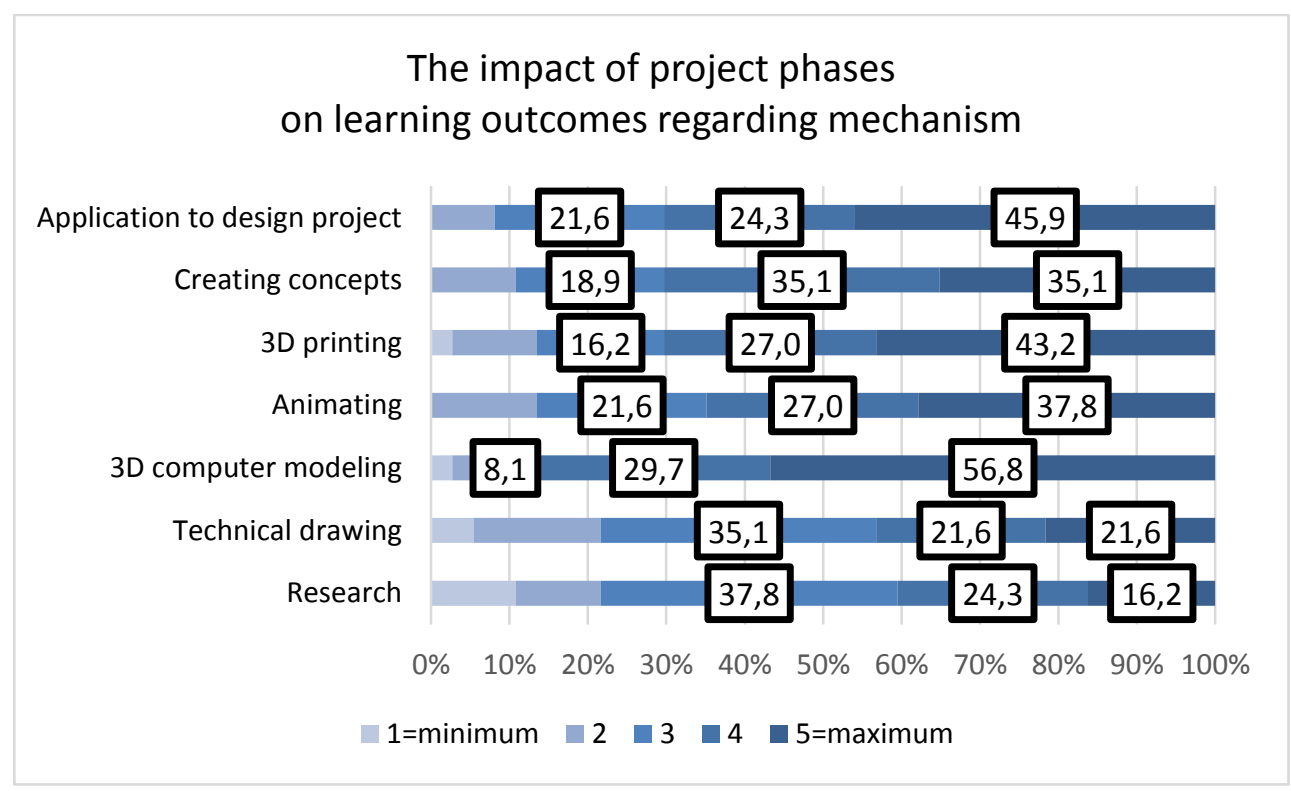

Figure 5. Results of post-project questionnaire part 1 
Table 6. Basic statistics of the results of post-project questionnaire part 1

\begin{tabular}{cccccccccc}
\hline & Total & 1 & 2 & 3 & 4 & 5 & Total & SD \\
$(\mathrm{n})$ & $(\%)$ & $(\%)$ & $(\%)$ & $(\%)$ & $(\%)$ & Mean \\
\hline Research & 37 & 10,8 & 10,8 & 37,8 & 24,3 & 16,2 & 100 & 3,24 \\
Technical drawing & 37 & 5,4 & 16,2 & 35,1 & 21,6 & 21,6 & 100 & 3,37 & 1,188 \\
3 computer modeling & 37 & 2,7 & 2,7 & 8,1 & 29,7 & 56,8 & 100 & 4,35 & 0,949 \\
Animating & 37 & 0 & 13,5 & 21,6 & 27,0 & 37,8 & 100 & 3,89 & 1,075 \\
3D printing & 37 & 2,7 & 10,8 & 16,2 & 27,0 & 43,2 & 100 & 3,97 & 1,142 \\
$\begin{array}{c}\text { Creating concepts } \\
\text { Application to design }\end{array}$ & 37 & 0 & 10,8 & 18,9 & 35,1 & 35,1 & 100 & 3,94 & 0,998 \\
project & 37 & 0 & 8,1 & 21,6 & 24,3 & 45,9 & 100 & 4,08 \\
\hline
\end{tabular}

Part 2: In this part, the most challenging phase of the project was asked to check and to explain.

The results of responses to the most challenging phase of the project were demonstrated in Figure 6. As seen in the pie chart, the most frequently occurring response was "application of mechanism to design project (action learning)" with 64,9\%. "Research" and "technical drawing" received the lowest rating with $2,7 \%$.

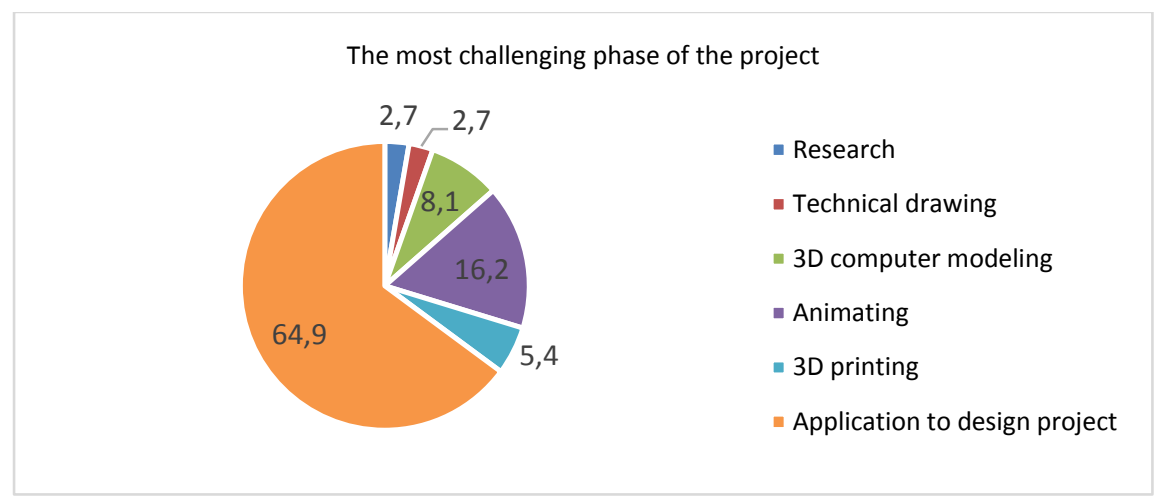

Figure 6. Results of post-project questionnaire part 2

The reasons of the students marked "application of mechanism to design project (action learning)" as the most challenging phase of the project are summarized as follows:

a. It was challenging that we have to apply assigned mechanism to design project.

b. Due to the complexity of the mechanisms, it was difficult to apply the mechanism to the design project and this made the process more exciting and ambitious.

c. We had to create too many design concepts to apply the mechanism appropriately; therefore, it made it the process difficult and more intensive.

d. Creating the form of mechanical game design depending on an assigned specific mechanism was difficult thus we have to implement all motional characteristics of the mechanism through various drafts in order to provide a creative game design.

e. Teamwork led to contradictory and challenging design ideas.

Explanations of the students who provided "animating" as the most challenging phase of the project are summarized as follows:

a. Since I have not enough knowledge and skills on animating, it was challenging to create motions of mechanisms leading to specific competencies.

b. I had trouble while animating motions of mechanism on Autodesk Fusion 360.

Part 3: In the third part, students rated their level of knowledge on Autodesk Fusion 360 and 3D printing for before and after the project.

As seen in Figure 7, before the project, knowledge of students on Autodesk Fusion 360 was centered upon average and above average level. After the project, the majority reached the above average level $(62,2 \%)$. 
Level of knowledge and competency on Autodesk Fusion 360

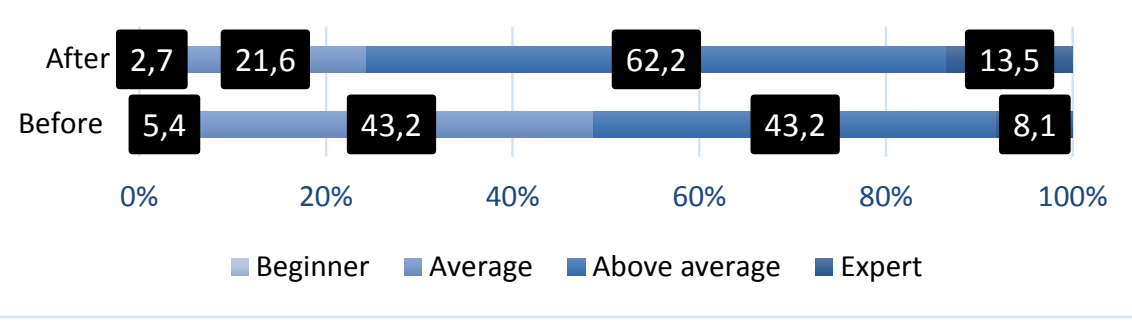

Figure 7. Results of post-project questionnaire part 3 about the level of knowledge and competency on Autodesk Fusion 360

A paired-samples t-test was conducted to compare the level of knowledge on Autodesk Fusion 360 before and after the project. There was a significant difference in the responses for before $(\mathrm{M}=2,5405$, $\mathrm{SD}=0,730091)$ and after $(\mathrm{M}=2,864865, \mathrm{SD}=0,673390)$ situations, $\mathrm{p}=, 000$ (Table 7).

As seen in Figure 8, before the project, knowledge of students on 3D printing was centered upon beginner and average level. After the project, the center shifted towards average and above average level with $54,1 \%$ and $43,2 \%$ respectively.

A paired-samples t-test was conducted to compare the level of knowledge on 3D printing before and after the project. There was a significant difference in the responses for before $(\mathrm{M}=1,6216, \mathrm{SD}=0,63907)$ and after $(\mathrm{M}=2,4865, \mathrm{SD}=0,55885)$ situations; $\mathrm{p}=, 000$ (Table 8$)$.

Table 7. Results of paired-samples t-test of post-project questionnaire part 3 (level of knowledge and

\begin{tabular}{llllllllll}
\hline & $\begin{array}{l}\text { Total } \\
(\mathrm{n})\end{array}$ & $\begin{array}{l}\text { Beginner } \\
(\%)\end{array}$ & $\begin{array}{l}\text { Average } \\
(\%)\end{array}$ & $\begin{array}{l}\text { Above average } \\
(\%)\end{array}$ & $\begin{array}{l}\text { Expert } \\
(\%)\end{array}$ & Total(\%) & Mean & SD & $\begin{array}{l}\text { Sig. (2- } \\
\text { tailed) }\end{array}$ \\
\hline Before & 37 & 5,4 & 43,2 & 43,2 & 8,1 & 100 & 2,5405 & 0,730091 &, 000 \\
After & 37 & 2,7 & 21,6 & 62,2 & 13,5 & 100 & 2,864865 & 0,673390 & \\
\hline
\end{tabular}

Table 8. Results of post-project questionnaire part three (level of knowledge and competency on 3D printing)

\begin{tabular}{llllllllll}
\hline & $\begin{array}{l}\text { Total } \\
(n)\end{array}$ & $\begin{array}{l}\text { Beginner } \\
(\%)\end{array}$ & $\begin{array}{l}\text { Average } \\
(\%)\end{array}$ & $\begin{array}{l}\text { Above } \\
\text { average } \\
(\%)\end{array}$ & $\begin{array}{l}\text { Expert } \\
(\%)\end{array}$ & $\begin{array}{l}\text { Total } \\
(\%)\end{array}$ & Mean & SD & $\begin{array}{l}\text { Sig. (2- } \\
\text { tailed) }\end{array}$ \\
\hline Before & 37 & 45,9 & 45,9 & 8,1 & 0 & 100 & 1,6216 &, 63907 &, 000 \\
After & 37 & 0 & 54,1 & 43,2 & 2,7 & 100 & 2,4865 &, 55885 & \\
\hline
\end{tabular}

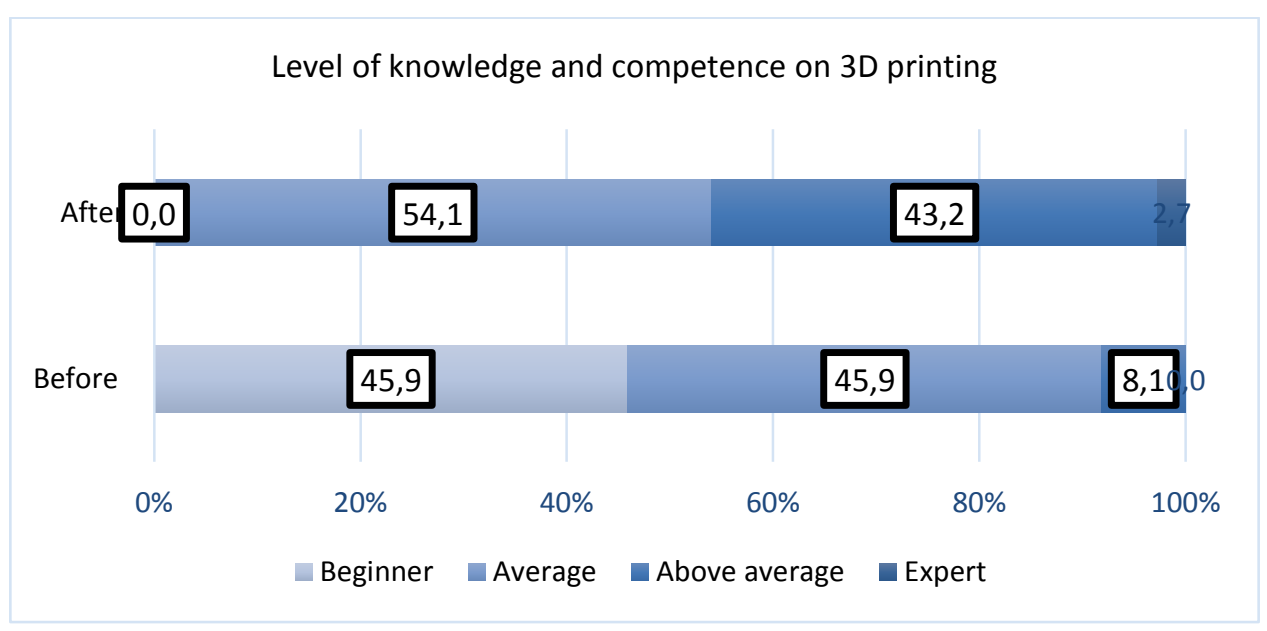

Figure 8. Results of post-project questionnaire part 3 about the level of knowledge and competency on 3D printing 
Part 4: In this part, students rated the acceptability of the 10 questions related with the project process on a Likert scale of 1 to 5 , with 1 corresponding to "strongly disagree" and 5 corresponding to "strongly agree".

The results of the fourth part of the questionnaire are demonstrated in Figure 9 and basic statistics were presented in Table 9. The questions that students rated are as follows:

Q1: 3D printed motion mechanisms allowed me to learn easier.

The responses to this question were largely positive with 51,4\% strongly agreeing and $32,4 \%$ agreeing and received fourth highest overall mean of 4,24.

Q2: 3D printed motion mechanisms allowed me to learn other teams' mechanisms.

The responses to this question were mixed with $10,8 \%$ disagreeing and $24,3 \%$ of the responses being neutral. The mean of all the responses was 3,91.

Q3: 3D printed motion mechanisms provided me to notice the mistakes made in $3 \mathrm{D}$ computer modeling.

The responses to this question were largely positive in spite of mixed with 5,4\% disagreeing and $10,8 \%$ of the responses being neutral and received third highest overall mean $(4,27)$ and third lowest standard deviation $(0,871)$.

Q4: The knowledge of mechanism gained throughout the project allowed me to create product design ideas easier.

The responses to this question were also mixed with $2,7 \%$ strongly disagreeing and $10,8 \%$ disagreeing and received overall mean of 3,73

Q5: Obligation to use the assigned mechanism limited my creativity in design process.

The responses to this question were largely neutral $(37,8 \%)$ and received the lowest overall mean $(3,03)$.

Q6: I can utilize the knowledge of mechanism gained for further projects.

The responses to this question were largely positive with only $8,1 \%$ of the responses being neutral and received the highest overall mean of 4,41 and the second lowest standard deviation of 0,644 .

Q7: Teamwork allowed us to create diverse creative product design ideas.

The responses to this question were mixed with 5,4\% strongly disagreeing and 13,5\% disagreeing and $13,5 \%$ of responses being neutral. The mean of all responses was 3,70 (the second lowest in data set) and standard deviation was 1,175 (the highest in data set).

Q8: This project has increased my motivation to work as a team.

The responses to this question were again mixed with 5,4\% strongly disagreeing and 18,9\% disagreeing and $18,9 \%$ of responses being neutral. The mean of all responses was 3,76 (the second lowest in data set) and standard deviation was 1,238 (the highest in data set).

Q9: This project increased my motivation to product design studio.

The responses to this question were largely positive with only $8,1 \%$ disagreeing and $13,5 \%$ of responses being neutral.

Q10: The project process was useful for me in general.

The responses to this question were again largely positive with only $8,1 \%$ of responses being neutral. The mean of all the responses was 4,38 which is second highest in data set and received a standard deviation of 0,639 which is the lowest in data set. 
The project process-related attributes

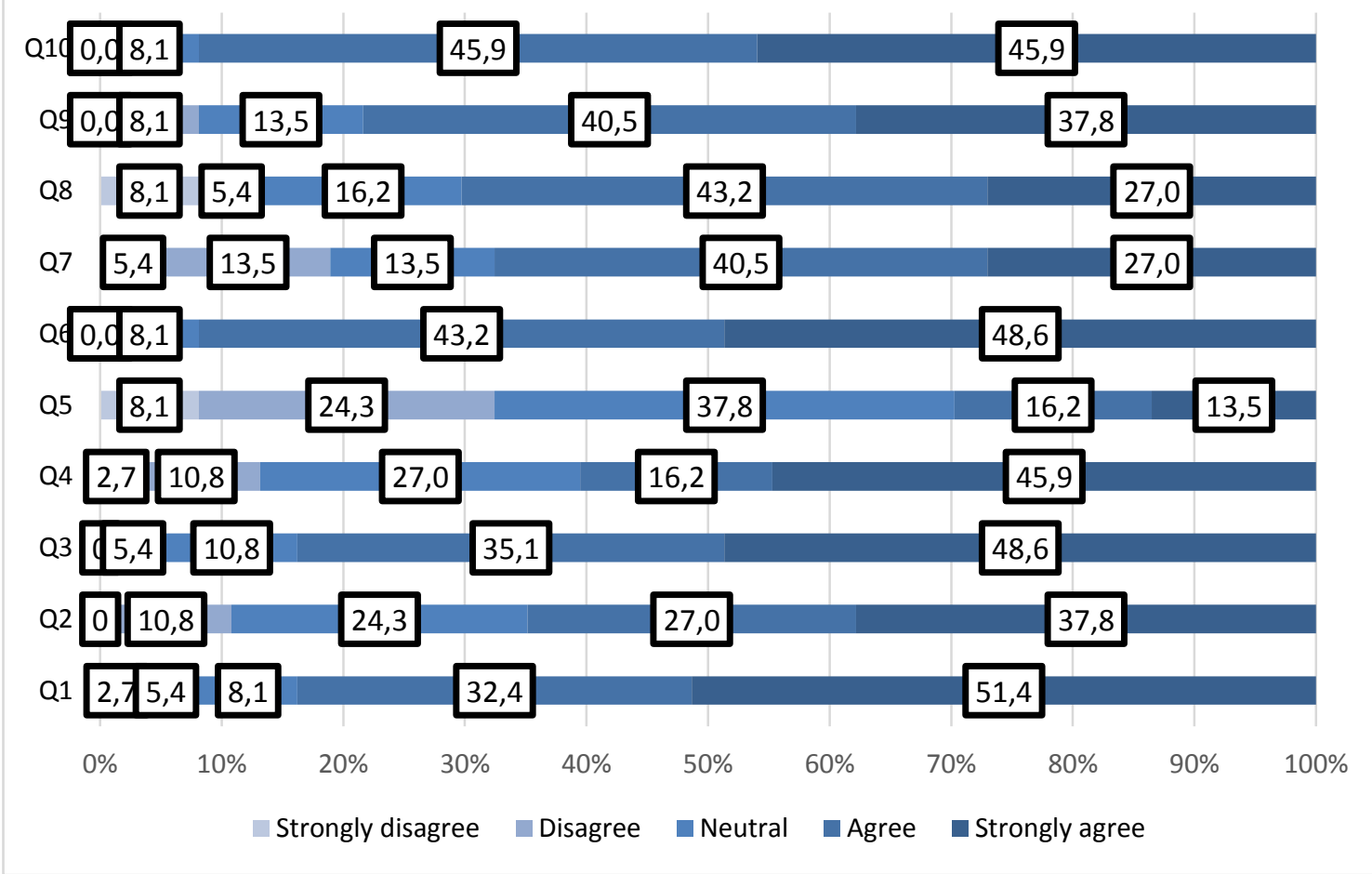

Figure 9. Results of post-project questionnaire part 4

Table 9. Basic statistics of the results of post-project questionnaire part four

\begin{tabular}{|c|c|c|c|c|c|c|c|c|c|}
\hline & $\begin{array}{l}\text { Total } \\
(n)\end{array}$ & $\begin{array}{l}\text { Strongly } \\
\text { disagree } \\
(\%)\end{array}$ & $\begin{array}{l}\text { Disagree } \\
(\%)\end{array}$ & $\begin{array}{l}\text { Neutral } \\
(\%)\end{array}$ & $\begin{array}{l}\text { Agree } \\
(\%)\end{array}$ & $\begin{array}{l}\text { Strongly } \\
\text { agree } \\
(\%)\end{array}$ & $\begin{array}{l}\text { Total } \\
(\%)\end{array}$ & Mean & $S D$ \\
\hline$Q 1$ & 37 & 2,7 & 5,4 & 8,1 & 32,4 & 51,4 & 100 & 4,24 & 1,011 \\
\hline$Q 2$ & 37 & 0 & 10,8 & 24,3 & 27 & 37,8 & 100 & 3,91 & 1,037 \\
\hline$Q^{3}$ & 37 & 0 & 5,4 & 10,8 & 35,1 & 48,6 & 100 & 4,27 & 0,871 \\
\hline$Q^{4}$ & 37 & 2,7 & 10,8 & 27 & 29,7 & 29,7 & 100 & 3,73 & 1,097 \\
\hline$Q 5$ & 37 & 8,1 & 24,3 & 37,8 & 16,2 & 13,5 & 100 & 3,03 & 1,142 \\
\hline Q6 & 37 & 0 & 0 & 8,1 & 43,2 & 48,6 & 100 & 4,41 & 0,644 \\
\hline$Q^{2}$ & 37 & 5,4 & 13,5 & 13,5 & 40,5 & 27 & 100 & 3,70 & 1,175 \\
\hline$\widetilde{Q} 8$ & 37 & 8,1 & 5,4 & 16,2 & 43,2 & 27 & 100 & 3,76 & 1,164 \\
\hline$Q^{9}$ & 37 & 0 & 8,1 & 13,5 & 40,5 & 37,8 & 100 & 4,08 & 0,924 \\
\hline$Q 10$ & 37 & 0 & 0 & 8,1 & 45,9 & 45,9 & 100 & 4,38 & 0,639 \\
\hline
\end{tabular}

\section{CONCLUSION}

Although it is reported that knowledge of mechanical designing and principles is an important item for industrial designers [6], the studies on teaching of mechanical mechanism to ID students are limited. In spite of its importance, mechanics-based courses are generally taught through traditional lecture-based style in ID departments also in Turkey. In addition, there is no integration between mechanics-based courses and design studio courses, which makes difficult for students to apply the knowledge of mechanism to the design projects.

This paper has proposed and presented a new teaching model combining of three main phases: Improving theoretical knowledge of mechanism and possible applications, in depth practical knowledge of specific mechanism and application of mechanism into design a process (action learning). Integration of this teaching model to the design project aimed to improve ID students' learning experience providing transference of theoretical knowledge into practice. The evaluation of this teaching model focuses on project observations and post-questionnaire to analyze objectively the appropriateness of it.

Observations of project process and submissions revealed that in all three phases of the project the expected outcomes have been highly obtained. All phases fed each other and the knowledge of mechanisms cumulated from the first phase to final phase. Research and technical drawings of mechanisms provided 
students with a sufficient theoretical knowledge for utilizing in the phase of practical knowledge. Practical knowledge phase reinforced the knowledge of mechanism by transferring theory to practice with 3D computer modeling, 3D printing and animating. 3D computer modeling enabled students to comprehend the parts of the mechanisms and the relations between them. Having to model for 3D printing provided to learn about the optimum wall thicknesses of the parts and tolerances between them. It also contributed to gain concrete experience about manufacturing principles. These applications increased their practical knowledge of 3D modeling and printing. Cumulative knowledge gained throughout the project facilitated the application of mechanism to mechanical game design project.

The results of post-questionnaire indicated that the students thought that although the most challenging phase was application of mechanism, it was also the second most effective phase on their learning of mechanism. Therefore, application of mechanism to a design project is vital to gain sufficient competencies for comprehending the function of the mechanisms. Accordingly, mechanics-based courses in ID departments must be revised in terms of their contents. They should introduce the concept of problembased action learning (learning by doing) inside the learning system since this style emphasizes direct utilization of the otherwise very abstract knowledge of ecientific theories. Apart from that, such courses should collaborate with design studio courses within in a problem-based action learning environment. Thus, the further step of this combined teaching model will be the extension of the applied model of action learning model to problem based learning through simultaneous or consecutive mechanics related course and product design studio.

The results of post-questionnaire also indicated that students were agreed with that the project were effective in terms of their motivation to the course and useful for further projects. Thus, the first thing to do in the product design studios is to motivate students' interest. An emphasis on case studies in practical design greatly improves industrial design students' abilities in applying mechanical design theory.

Overall results of the project established that this combined teaching model of mechanism improved ID students' learning outcomes and competencies in terms of transferring the gained theoretical and practical knowledge to the action learning through creating a game design including the concrete function of the mechanism inside the system.

Although this study focuses on teaching of mechanism, the general approach on implementation and evaluation could be extrapolated to other ID courses.

\section{REFERENCES}

[1] WDO (2016). Retrieved March 15, 2017, from http://wdo.org/about/definition/

[2] NASAD (2016). Retrieved March 15, 2017, from https://nasad.arts-accredit.org/accreditation/general-information/definitions/

[3] MSU DENVER (2016). Retrieved March 15, 2017, from https://msudenver.edu/ind/

[4] ND (2016). Retrieved March 20, 2017, from http://artdept.nd.edu/undergraduate-programs/design/industrial-design/

[5] NJIT (2016). Retrieved March 20, 2017, from http://design.njit.edu/

[6] Liu, S. F., Lee, Y. L., Lin, Y. Z., \& Tseng, C. F. Applying quality function deployment in industrial design curriculum planning. International Journal of Technology and Design Education, 2013; 23(4), 1147-1160.

[7] Liu, X., Sun Y., \& Wu, J. Reforming the teaching of mechanical design for industrial design students. World Transactions on Engineering and Technology Education, 2013; 11(4),406-411.

[8] Bingham, G. A., Southee, D. J., \& Page, T. Meeting the expectation of industry: an integrated approach for the teaching of mechanics and electronics to design students. European Journal of Engineering Education, 2015; 40(4), 410-431.

[9] Chou, Y.P., Hsu, M. Teaching Scientific Thinking to Students of Industrial Design. IASDR07, International Association of Societies of Design Research, 2007; p.1-16.

[10] Demirbas, O. O., \& Demirkan, H. Learning styles of design students and the relationship of academic performance and gender in design education. Learning and instruction, 2007; 17(3), 345-359.

[11] Demirbaş, Ö. O. The relation of learning styles and performance scores of the students in interior architecture education.(PhD). Bilkent University, Ankara, Turkey. 2001.

[12] Uluoğlu, B. Mimari tasarım eğitimi: Tasarım bilgisi bağlamında stüdyo eleştirileri, (PhD). İTÜ, İstanbul, Turkey. 1990.

[13] Hook, J., Hjermitslev, T., Iversen, O. S., \& Olivier, P. (2013, September). The ReflecTable: Bridging the Gap between Theory and Practice in Design Education. In INTERACT (2) (pp. 624-641).

[14] Schon, D. A. Educating the reflective practitioner: Towards a new design for teaching in the professions. San Francisco: JosseyBass Publishers. 1987. 